\title{
Characteristics of tropospheric ozone depletion events in the Arctic spring: analysis of the ARCTAS, ARCPAC, and ARCIONS measurements and satellite $\mathrm{BrO}$ observations
}

\author{
J.-H. Koo ${ }^{1}$, Y. Wang ${ }^{1}$, T. P. Kurosu ${ }^{2, *}$, K. Chance ${ }^{2}$, A. Rozanov ${ }^{3}$, A. Richter ${ }^{3}$, S. J. Oltmans ${ }^{4}$, A. M. Thompson ${ }^{5}$, \\ J. W. Hair ${ }^{6}$, M. A. Fenn ${ }^{6}$, A. J. Weinheimer ${ }^{7}$, T. B. Ryerson ${ }^{4}$, S. Solberg ${ }^{8}$, L. G. Huey ${ }^{1}$, J. Liao ${ }^{1}$, J. E. Dibb ${ }^{9}$,

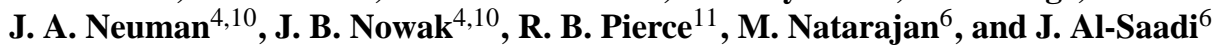 \\ ${ }^{1}$ School of Earth and Atmospheric Sciences, Georgia Institute of Technology, Atlanta, GA, USA \\ ${ }^{2}$ Harvard-Smithsonian Center for Astrophysics, Cambridge, MA, USA \\ ${ }^{3}$ Institute of Environmental Physics, University of Bremen, Bremen, Germany \\ ${ }^{4}$ Earth System Research Laboratory, National Oceanic and Atmospheric Administration, Boulder, CO, USA \\ ${ }^{5}$ Department of Meteorology, Pennsylvania State University, University Park, Pennsylvania, USA \\ ${ }^{6}$ NASA Langley Research Center, Hampton, VA, USA \\ ${ }^{7}$ National Center for Atmospheric Research, Boulder, CO, USA \\ ${ }^{8}$ Norwegian Institute for Air Research (NILU), Kjeller, Norway \\ ${ }^{9}$ University of New Hampshire, Durham, NH, USA \\ ${ }^{10}$ Cooperative Institute for Research in Environmental Sciences (CIRES), University of Colorado Boulder, Boulder, CO, USA \\ ${ }^{11}$ NOAA National Environmental Satellite, Data, and Information Service, Madison, Wisconsin, USA \\ *now at: NASA Jet Propulsion Laboratory, Pasadena, CA, USA
}

Correspondence to: J.-H. Koo (jkoo7@gatech.edu)

Received: 9 May 2012 - Published in Atmos. Chem. Phys. Discuss.: 2 July 2012

Revised: 24 September 2012 - Accepted: 15 October 2012 - Published: 29 October 2012

\begin{abstract}
Arctic ozone depletion events (ODEs) are caused by halogen catalyzed ozone loss. In situ chemistry, advection of ozone-poor air mass, and vertical mixing in the lower troposphere are important factors affecting ODEs. To better characterize the ODEs, we analyze the combined set of surface, ozonesonde, and aircraft in situ measurements of ozone and bromine compounds during the Arctic Research of the Composition of the Troposphere from Aircraft and Satellites (ARCTAS), the Aerosol, Radiation, and Cloud Processes affecting Arctic Climate (ARCPAC), and the Arctic Intensive Ozonesonde Network Study (ARCIONS) experiments (April 2008). Tropospheric BrO columns retrieved from satellite measurements and back trajectory calculations are also used to investigate the characteristics of observed ODEs. In situ observations from these field experiments are inadequate to validate tropospheric $\mathrm{BrO}$ columns derived from satellite measurements. In view of this difficulty, we construct an ensemble of tropospheric column $\mathrm{BrO}$
\end{abstract}

estimates from two satellite (OMI and GOME-2) measurements and with three independent methods of calculating stratospheric $\mathrm{BrO}$ columns. Furthermore, we select analysis methods that do not depend on the absolute magnitude of column BrO, such as time-lagged correlation analysis of ozone and tropospheric column $\mathrm{BrO}$, to understand characteristics of ODEs. Time-lagged correlation analysis between in situ (surface and ozonesonde) measurements of ozone and satellite derived tropospheric $\mathrm{BrO}$ columns indicates that the ODEs are due to either local halogen-driven ozone loss or short-range $(\sim 1$ day) transport from nearby regions with ozone depletion. The effect of in situ ozone loss is also evident in the diurnal variation difference between low (10th and 25 th percentiles) and higher percentiles of surface ozone concentrations at Alert, Canada. Aircraft observations indicate low-ozone air mass transported from adjacent high-BrO regions. Correlation analyses of ozone with potential temperature and time-lagged tropospheric BrO column show that 
the vertical extent of local ozone loss is surprisingly deep (1-2 km) at Resolute and Churchill, Canada. The unstable boundary layer during ODEs at Churchill could potentially provide a source of free-tropospheric $\mathrm{BrO}$ through convective transport and explain the significant negative correlation between free-tropospheric ozone and tropospheric $\mathrm{BrO}$ column at this site.

\section{Introduction}

Tropospheric ozone depletion events (ODEs) in the Arctic spring were first found in the early 1980s (Oltmans, 1981), and Barrie et al. (1988) showed that the ODEs were associated with high particulate bromide concentrations. Catalytic ozone loss processes involving halogens, especially heterogeneous bromine chemistry, are believed to be the main cause of the ODEs (e.g., Fan and Jacob, 1992; Sander and Crutzen, 1996; Tang and McConnell, 1996). During these events, aqueous-phase reactions involving soluble species such as $\mathrm{HOBr}, \mathrm{BrNO}_{3}, \mathrm{HBr}$ and $\mathrm{HCl}$ play important roles in the conversion of the gas and aqueous phase reservoir species into reactive bromine radicals (e.g., Vogt et al., 1996; Sander et al., 1999; Foster et al., 2001). In addition to aerosols, potentially important medias for heterogeneous reactions include snowpack (Michalowski et al., 2000; Simpson et al., 2005; Toyota et al., 2011), frost flower (Kaleschke et al., 2004; Piot and von Glasow, 2008), and first-year sea ice (Simpson et al., 2007). Recently, blowing snow was also suggested to be a source of bromine (Jones et al., 2009; Yang et al., 2010).

Transport of ozone-poor air mass is another important factor contributing to the observed ODEs. The transport pattern during ODE periods was investigated using the analysis of synoptic-scale meteorology patterns (Hopper et al., 1998; Strong et al., 2002; Zhao et al., 2008). Back trajectory analysis is often useful to identify and quantify the potential source regions of ozone-poor air mass (Bottenheim and Chan, 2006). The rate-limiting step of bromine-driven ozone depletion is mostly through the self-reaction of $\mathrm{BrO}$ (e.g., Hausmann and Platt, 1994; Zeng et al., 2006). Analyses of satellite measurements of $\mathrm{BrO}$, sea ice conditions, and back trajectories suggest that the ozone-poor air mass is usually transported from high-BrO regions (Zeng et al., 2003, 2006; Kaleschke et al., 2004; Simpson et al., 2007; Bottenheim et al., 2009; Gilman et al., 2010; Nghiem et al., 2012; Oltmans et al., 2012). Not all ODEs can be explained by the transport effect (Jacobi et al., 2006), implying the importance of in situ chemistry.

The characteristics of ODEs are affected by ambient conditions. Although high $\mathrm{BrO}$ enhancements can be related to cold temperature (Pöhler et al., 2010; Nghiem et al., 2012), ODEs occur in a wide range of temperature (Zeng et al., 2003; Bottenheim et al., 2009; Neuman et al., 2010). Atmospheric stability affects the vertical profile of ODEs (Botten- heim et al., 2002; Tarasick and Bottenheim, 2002; Jacobi et al., 2006). Generally ODEs occur in a stable layer, which effectively isolates depleted ozone air mass from mixing with ozone-rich air mass above (Lehrer et al., 2004; Bottenheim et al., 2009; Jacobi et al., 2010). However, ODEs also occur when there is vertical mixing from the surface (McElroy et al., 1999; Jones et al., 2010).

The Arctic Research of the Composition of the Troposphere from Aircraft and Satellites (ARCTAS), the Aerosol, Radiation, and Cloud Processes affecting Arctic Climate (ARCPAC), and the Arctic Intensive Ozonesonde Network Study (ARCIONS) experiments in April 2008 made extensive aircraft and ozonesonde measurements. We combine these measurements with surface and satellite observations and back trajectory calculations to analyze the spatiotemporal characteristics of ODEs. Following Tarasick and Bottenheim (2002), we define two categories of ODEs, strong ODEs (ozone mixing ratio $<10 \mathrm{ppbv}$ ) and partial ODEs (ozone mixing ratio between 10 to $20 \mathrm{ppbv}$ ). We focus on two aspects of the ODE characteristics: the relative importance of in situ chemistry compared to transport of ozonepoor air mass, and the impacts of tropospheric $\mathrm{BrO}$ distributions on ODEs in the Arctic. Available in situ BrO observations are too limited (e.g., Neuman et al., 2010; Liao et al., 2012) to be applied directly to analyze ODE characteristics. The retrievals of tropospheric $\mathrm{BrO}$ columns from satellite measurements are problematic (e.g., Choi et al., 2012), but can potentially provide useful information on tropospheric $\mathrm{BrO}$ distributions (e.g., Zeng et al., 2003, 2006). A particular challenge in this work was to define how useful information on ODE characteristics can be obtained from careful analysis of satellite $\mathrm{BrO}$ products while taking into account the uncertainties in these products. We describe the in situ measurement data, the retrievals of tropospheric $\mathrm{BrO}$ columns from satellite observations, and meteorological and back trajectory simulations in Sect. 2. Detailed analyses of these data are presented in Sect. 3. We discuss in Sect. 4 the feasibility of using available in situ $\mathrm{BrO}$ measurements to validate satellite column $\mathrm{BrO}$ products and the implications of our analysis results for satellite $\mathrm{BrO}$ product validation. Conclusions are given in Sect. 5.

\section{Data description}

\subsection{In situ measurements}

\subsubsection{Ozone and temperature}

We used surface ozone measurements at three monitoring stations in the Arctic located in Barrow $\left(71.3^{\circ} \mathrm{N}, 156.8^{\circ} \mathrm{W}\right)$, Alaska in the US (Oltmans and Levy, 1994) and Alert $\left(82.5^{\circ} \mathrm{N}, 62.3^{\circ} \mathrm{W}\right)$, Nunavut in Canada (Anlauf et al., 1994), and Zeppelin mountain $\left(78.9^{\circ} \mathrm{N}, 11.9^{\circ} \mathrm{E}\right)$ at Spitsbergen, Norway (Solberg et al., 1996). All three sites are in coastal 
regions. The Barrow site (near the sea level) is located along the northern coast of Alaska and surrounded by the Chukchi Sea to the west and the Beaufort Sea to the north. The station, operated by the NOAA Earth System Research Laboratory (ESRL), has observed surface ozone since the 1970s. The Alert site (at $200 \mathrm{~m}$ above the sea level) is located on the northeastern tip of Ellesmere Island close to Greenland. The Canadian Air and Precipitation Monitoring Network (CAP$\mathrm{MoN}$ ) of Environment Canada has collected surface ozone observations at this site from the 1990s. The Zeppelin (ZPL) mountain site is located at a fjord on a mountain ridge of $474 \mathrm{~m}$ altitude close to Ny-Ålesund, which is on the island Spitsbergen in the Norwegian Arctic Ocean. The Norwegian Institute for Air Research (NILU) started surface ozone measurements at this site in the 1989 and ODEs were often detected (Solberg et al., 1996; Bottenheim and Chan, 2006). The optical technique using the strong UV absorption band (e.g., Oltmans et al., 2012) was used to measure ozone at all three sites. Hourly averaged ozone data were used in this study. The accuracy of ozone dataset is in the range of 0.52 ppbv (Helmig et al., 2007), adequate for the study. Surface temperature measurements at Barrow and Alert were obtained from the NOAA National Climatic Data Center (NCDC), and temperature measurements at ZPL were obtained from NILU.

Ozonesonde measurements were made during the ARCIONS campaign for 1-20 April 2008 (Thompson et al., 2011). Balloons carrying the Electrochemical Concentration Cell (ECC) instrument were launched daily around local noontime at Barrow, Alaska in the US $\left(71.3^{\circ} \mathrm{N}\right.$, $\left.156.8^{\circ} \mathrm{W}\right)$, Resolute, Nunavut in Canada $\left(74.7^{\circ} \mathrm{N}, 95.0^{\circ} \mathrm{W}\right)$, and Churchill, Manitoba in Canada $\left(58.7^{\circ} \mathrm{N}, 94.1^{\circ} \mathrm{W}\right)$.

In spring 2008, aircraft measurements were made during two extensive field campaigns, the ARCTAS and ARCPAC experiments. Ozone was measured in situ by the chemiluminescence method on the NASA DC-8 (Jacob et al., 2010) and NOAA WP-3D (Brock et al., 2010) aircraft missions. Ozone and potential temperature data used in this study are from 7 DC-8 flights (on 4, 5, 8, 9, 12, 16, and 17 April) and 5 WP-3D flights (on 12, 15, 18, 19, and 21 April). The vertical distribution of ozone was also measured by the ultraviolet Differential Absorption Lidar (UV-DIAL) on DC-8 (Fenn et al., 1999; Browell et al., 2003). The high-resolution (151 layers) UV-DIAL profiles of ozone provided additional cases of ODEs not detected by the in situ measurements. We analyze in situ and DIAL aircraft observations below $1 \mathrm{~km}$ where ODEs usually occurred.

\subsubsection{Bromine species}

In situ bromine measurements from aircraft during the ARCTAS and ARCPAC experiments were used for the comparison with satellite-derived tropospheric $\mathrm{BrO}$ columns. We used in situ observations of $\mathrm{BrO}$, soluble bromide, and $\mathrm{Br}_{2}+\mathrm{HOBr}$ (Neuman et al., 2010; Liao et al., 2012) in the lowest $2 \mathrm{~km}$. $\mathrm{BrO}$ and $\mathrm{Br}_{2}+\mathrm{HOBr}$ were measured by a chemical ionization mass spectrometer (CIMS) and soluble bromide by a mist chamber (Dibb et al., 2010). Soluble bromide includes $\sim 100 \%$ of $\mathrm{Br}_{2}, \mathrm{HOBr}$, and $\mathrm{HBr}$ and $40 \%$ for $\mathrm{BrO}$ (Liao et al., 2012). The uncertainty of measurements is $\pm 40 \%$ with detection limits of $2-5$ pptv for $\mathrm{BrO}$, $\pm 15 \%+0.5 \mathrm{pptv}$ for soluble bromide, and $15 \%+2 \mathrm{pptv}$ for $\mathrm{Br}_{2}+\mathrm{HOBr}$ (Neuman et al., 2010; Liao et al., 2012).

\subsection{Tropospheric BrO vertical column estimates based on satellite measurements}

Tropospheric $\mathrm{BrO}$ columns from satellite observations are good indicators of ODEs (e.g., Zeng et al., 2003, 2006). We use the residual method (e.g., Zeng et al., 2003; Theys et al., 2011; Choi et al., 2012) to derive tropospheric vertical columns of BrO. In this method, we need the total vertical $\mathrm{BrO}$ columns retrieved from satellite sensors, estimates of the stratospheric $\mathrm{BrO}$ columns, and stratospheric and tropospheric air mass factors (ratio of the slant column to the vertical column at a given vertical range) calculated from a radiative transfer model. Tropospheric vertical columns of $\mathrm{BrO}$ are obtained by subtracting the estimated stratospheric columns from the satellite total vertical $\mathrm{BrO}$ columns, followed by air mass factor correction. We used the total vertical columns of $\mathrm{BrO}$ from two satellite instruments, the Ozone Monitoring Instrument (OMI, Aura satellite) (Kurosu and Chance, 2011) and the Global Ozone Monitoring Experiment 2 (GOME-2, MetOp satellite) (Begoin et al., 2010). We did not use tropospheric $\mathrm{BrO}$ columns at latitudes higher than $85^{\circ}$ north since the uncertainty of retrieval is very large due to large solar zenith angles (Richter et al., 1998; Zeng et al., 2003; Choi et al., 2012).

Retrievals of tropospheric $\mathrm{BrO}$ columns from satellite measurements are quite uncertain, particularly in the estimate of stratospheric BrO columns (e.g., Choi et al., 2012). During our analysis period, in situ $\mathrm{BrO}$ observations are too limited and they do not provide enough quantitative constraints to validate satellite tropospheric $\mathrm{BrO}$ column products (the details will be discussed in Sect. 4). This lack of quantitative validation, however, does not imply that satellite $\mathrm{BrO}$ measurements do not provide useful information in the analysis of the ODE characteristics. For example, if ODEs were driven by $\mathrm{BrO}$ chemistry, we expect that the air mass of an ODE had encountered high $\mathrm{BrO}$ previously. The question to analyze is, therefore, whether or not there is an enhancement of BrO along the back trajectory of the ODE air mass. A key point here is that the enhancement can be relative to $\mathrm{BrO}$ measurements in other regions. We do not necessarily need the absolute magnitude of $\mathrm{BrO}$ column or concentration. The appropriate statistical method is correlation analysis between $\mathrm{BrO}$ along the air mass back trajectory and ozone. In correlation analysis, it is the variation not absolute magnitude that matters. 
In order to take into account the uncertainties in the estimates of stratospheric $\mathrm{BrO}$ vertical columns, we use three different estimate methods. These methods give different estimates of latitudinal/longitudinal variations in stratospheric $\mathrm{BrO}$ column and consequently in tropospheric BrO column. Most importantly, the estimated stratospheric BrO columns using these methods are independent from one another and should not introduce an unphysical correlation with tropospheric ozone. Consequently the uncertainty in the retrieval method can reduce or even eliminate the (anti)correlations between ozone and $\mathrm{BrO}$, but it should not produce false correlations consistently.

If we can establish consistent (anti)correlations between ozone and time-lagged tropospheric $\mathrm{BrO}$, we should be able to learn characteristics of ODEs from the correlation information without the need to know if the magnitudes of tropospheric BrO columns are correct. In fact, even the values of (anti)correlations between ozone and $\mathrm{BrO}$ are not that important. It is the change of the (anti)correlation between ozone and $\mathrm{BrO}$ with time or altitude that provides useful information on the importance of in situ chemistry relative to transport and on the vertical extent of bromine-driven ozone loss.

The three methods we chose in this study to estimate stratospheric $\mathrm{BrO}$ columns from satellite measurements are as follows. The first one is the 20th percentile method, in which we assume that the lowest 20th percentile among all total $\mathrm{BrO}$ vertical columns of each $80-\mathrm{km}$ latitude bin is the stratospheric $\mathrm{BrO}$ column. In this estimate, the longitudinal variations of satellite observed $\mathrm{BrO}$ columns are assumed to reside all in the troposphere. In the other two estimates, we include longitudinal variations of stratospheric $\mathrm{BrO}$ columns. In the second estimate, we derive stratospheric BrO columns using BrO profiles from limb measurements of the SCanning Image Absorption Spectrometer for Atmospheric Cartography (SCIAMACHY) measurements (Sinnhuber et al., 2005; Rozanov et al., 2011). Here, the stratospheric $\mathrm{BrO}$ data of version 3.2 provided by the Institute of Environmental Physics, University of Bremen (Rozanov et al., 2011) are used. The averaging kernels imply that the BrO profile measurements from SCIAMACHY are sensitive down to about $15 \mathrm{~km}$ altitude. Therefore, we estimate stratospheric $\mathrm{BrO}$ profile below $15 \mathrm{~km}$ by extrapolation as follows: since the SCIAMACHY limb sounding is sparse, we use the mean $\mathrm{BrO}$ profile for latitude bins of 10 degrees. We assume the stratospheric $\mathrm{BrO}$ mixing ratio profile to be a second-order polynomial function of altitude. We then extrapolate the polynomial fit obtained between 15 and $33 \mathrm{~km}$ to the tropopause. We integrate the obtained BrO profile from the tropopause to the upper limit of SCIAMACHY $\mathrm{BrO}$ profile $(33 \mathrm{~km})$. We use the reanalysis data from the National Center for Environmental Prediction/National Center for Atmospheric Research (NCEP/NCAR) (Kalnay et al., 1996) to calculate the tropopause height. Hereafter, we refer to these stratospheric BrO columns as the SCIA2ND method. In the third approach, we estimate the stratospheric
BrO columns calculated by the Regional Air Quality Modeling System (RAQMS) by zonal scaling such that the zonal mean values match the estimates from the 20th percentile method since RAQMS estimated stratospheric columns are too low compared to the previous two methods. By subtracting 3 sets of stratospheric column estimates from the total columns of OMI and GOME-2, we obtain 6 sets of tropospheric BrO columns (OMI-20th, OMI-SCIA2ND, OMIRAQMS, GOME-2-20th, GOME-2-SCIA2ND, and GOME2-RAQMS).

The in situ aircraft observations of $\mathrm{BrO}, \mathrm{Br}_{2}+\mathrm{HOBr}$, and soluble bromide are used to investigate to what extent satellite products capture the distributions of lower tropospheric BrO. To correlate with tropospheric BrO columns, we integrate in situ aircraft observations of $\mathrm{BrO}, \mathrm{Br}_{2}+\mathrm{HOBr}$, and soluble bromide from the surface to 7 altitude levels $(100,300,500,750,1000,1500$, and $2000 \mathrm{~m})$, respectively. The vertical profile of correlation coefficients between these integrated concentrations of bromine compounds and retrieved tropospheric $\mathrm{BrO}$ columns are calculated (see the Supplement, Figs. S1-4).

The analysis does not quantify the uncertainties in the derived tropospheric $\mathrm{BrO}$ columns, but the large separation of correlation coefficients indicates that the products have different characteristics. As discussed previously, the uncertainty of satellite retrievals can affect the (anti)correlations between ozone and $\mathrm{BrO}$. The six products generally show reasonably good consistency in the correlations between ozone and $\mathrm{BrO}$ as we will discuss in Sect. 3. For simplicity, we show in the paper only the analysis results using the GOME-2-SCIA2ND product, which has the highest correlations with in situ measurements of bromine compounds used in this study. The analysis results using the other five products are shown in the Supplement.

\subsection{Back trajectory simulation}

We used back trajectory calculations to investigate transport patterns for ODE regions. Back trajectories were computed using a kinematic model (Arimoto et al., 2008) based on meteorological simulations by the polar version of MM5 model (Bromwich et al., 2001), which was constrained by the NCEP global final analysis (FNL) grid data and DC-8 aircraft measurements. The details of polar MM5 model setup were described by Zeng et al. (2006). 5-day back trajectories were calculated every $10 \mathrm{~min}$ at the surface sites $(10 \mathrm{~m}$ above the ground) and at the altitudes of ozonesonde and aircraft measurements.

\section{Results and discussion}

\subsection{Surface and aircraft observed ODEs}

Observed ODEs can occur due to in situ bromine chemistry or transport of air mass with depleted ozone from another 

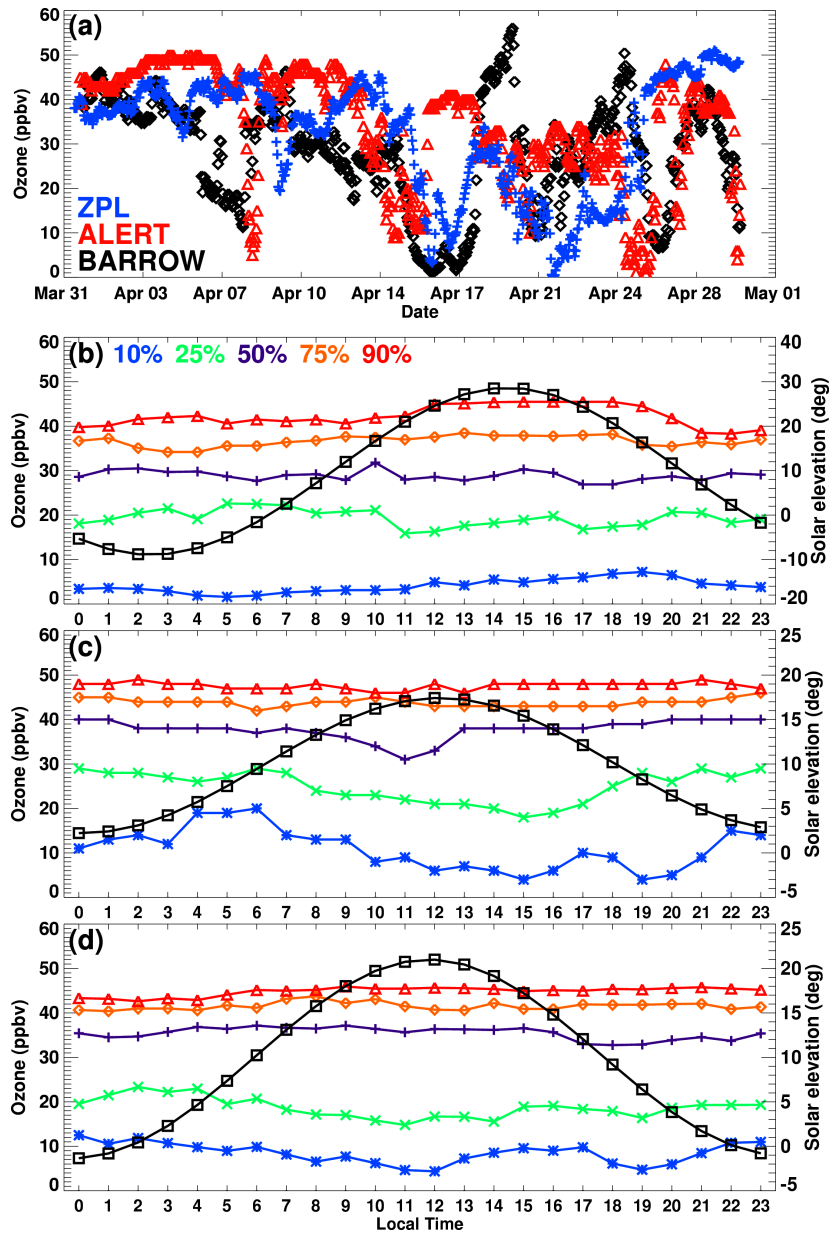

Fig. 1. (a) Time series of surface ozone concentrations in April 2008 at Barrow (black), Alert (red), and ZPL (blue), and the diurnal variations of surface ozone in percentiles of 10, 25, 50, 75, and $90 \%$ at (b) Barrow, (c) Alert, and (d) ZPL. To compute the ozone value for a given percentile, we bin the observations in a given hour together (30 data points in the hourly bin in April). We then calculate the percentile values in the hourly data bins. The 10th percentile value means that $90 \%$ of the data points are higher than this value in a data bin. The black line in panels (b), (c), and (d) shows the monthly mean solar elevation.

region. We first investigate the surface ozone observations at Barrow, Alert, and ZPL, which have better temporal coverage than ozonesonde or aircraft measurements.

\subsubsection{Diurnal ozone cycles}

Figure 1 shows the time series of surface ozone mixing ratios at Barrow, Alert, and ZPL in April 2008. All three sites have several ODEs during the analysis period, but ODEs at Barrow are the most frequent. To illustrate how the diurnal cycles of ODEs may differ from non-ODE days, we show the diurnal patterns of the 10th, 25th, 50th (median), 75th, and 90th percentile of hourly ozone at the sites. Also shown is the di- urnal solar elevation. For ozone above the 50th percentile, we see no clear diurnal patterns. For 25th percentile and particularly 10th percentile ozone, there is an increasingly clear diurnal pattern at Alert, lower at high solar elevations and higher at night. While more detailed bromine chemistry simulation is needed to understand the particular shape of the diurnal pattern, it is consistent with daytime bromine-driven ozone loss and nighttime recovery (by transport). In contrast, the diurnal patterns of 10th and 25th percentile ozone at Barrow are similar to those of higher-percentile ozone, which do not show a clear diurnal cycle. The 10th and 25th percentile ozone at ZPL shows larger diurnal variations than the higherpercentile ozone, but they are not as distinct as at Alert. These results indicate that in situ chemistry is more important at Alert and potentially so at ZPL but transport of ozone-poor air is more important at Barrow. We examine how transport patterns at the three sites differ.

\subsubsection{Transport patterns and $\mathrm{BrO}$ distributions}

We use back trajectory analysis to define the transport patterns. However, we also need information on the source regions of ozone-poor air masses. Since $\mathrm{BrO}$ enhancements indicate local ozone losses (Zeng et al., 2003, 2006), tropospheric $\mathrm{BrO}$ vertical columns from satellite measurements were used to estimate the source region of ozone-poor air mass in the Arctic. Figure 2 shows the monthly mean distribution of tropospheric BrO columns in April 2008. We can identify two high-BrO regions over the Chukchi Sea and the Canadian archipelago. Transport of ozone-poor air mass from these two regions could contribute to the observed ODEs.

We examine the relationships between ODEs and the air mass history of $\mathrm{BrO}$ exposure using 5-day back trajectories calculated from the polar MM5 simulations and tropospheric $\mathrm{BrO}$ vertical columns. We first computed tropospheric $\mathrm{BrO}$ vertical columns along the back trajectory using $\mathrm{BrO}$ measurements in the past 5 days. We then computed the correlations between hourly surface ozone concentrations and $\mathrm{BrO}$ vertical columns for the day of ozone observations (D-0) and the previous $i$ th day (D-i), where $i=1 \ldots 5$. (e.g., Parrish et al., 2010). These coefficients are then averaged to obtain the daily mean values for $\mathrm{D}-i(i=0 \ldots 5)$. In this type of timelagged correlation analysis, the $R$ value is calculated under similar conditions except for the time shift. Therefore, the change of $R$ value as a function of time is the most important.

Figure 3 shows the time-lagged daily mean correlation coefficients between ozone and 6 tropospheric $\mathrm{BrO}$ vertical column products at the three surface sites. As we previously discussed in Sect. 2.2, the uncertainties in the estimates of tropospheric $\mathrm{BrO}$ columns introduce noise into the correlation analysis that can reduce the correlation between ozone and column BrO. This effect appears to be a function of the strength of the correlation as well. Since the correlation ( $R$ value) is a function of covariance between ozone 


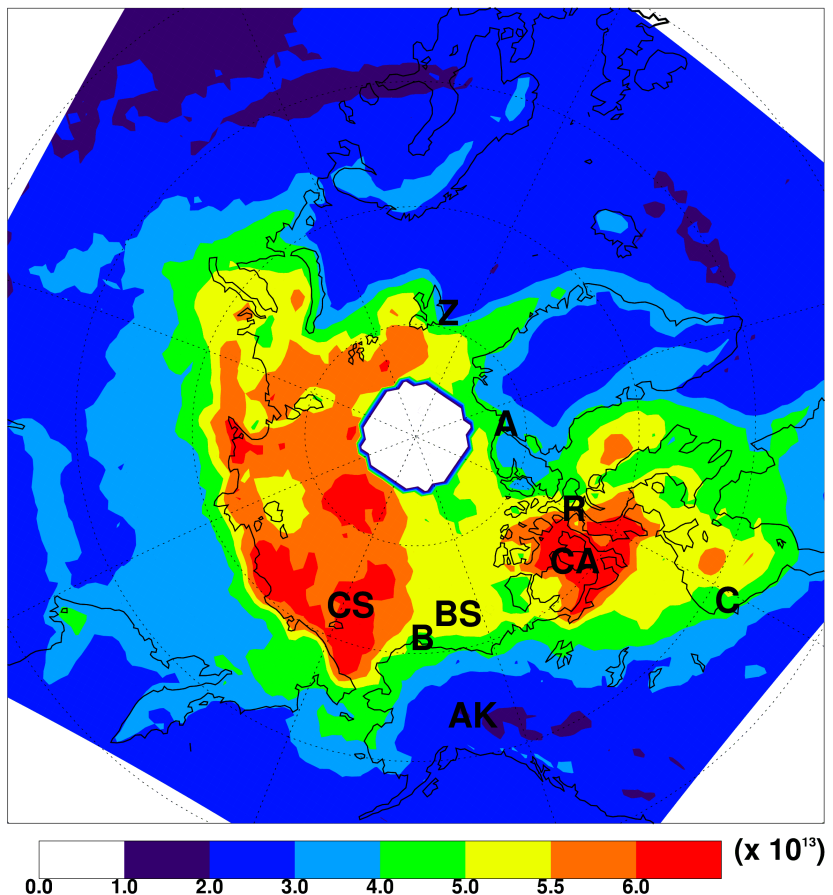

Fig. 2. Monthly mean tropospheric $\mathrm{BrO}$ vertical column density (VCD, molecules $\mathrm{cm}^{-2}$ ). "A" denotes the location of Alert, "B" for Barrow, "C" for Churchill, "R" for Resolute, and "Z" for Zeppelinfjellet (ZPL), "CA" for Canadian Archipelago, "CS" for Chukchi Sea, "BS" for Beaufort Sea, and AK for Alaska. The GOME-2SCIA2ND result is shown. Results for OMI-SCIA2ND, GOME-220th, OMI-20th, GOME-2-RAQMS, and OMI-RAQMS BrO VCDs show similar distribution patterns (Figs. S5, S6, S7, S8, and S9).

and tropospheric column $\mathrm{BrO}$, ODEs clearly drive the ozone variance at these sites, implying that the (anti)correlation is higher from the dataset with more variance. The number of hours and the duration of ODEs at Alert and ZPL are less than that at Barrow (Fig. 1). The highest (anti)correlation is indeed found at Barrow. The six estimates of tropospheric $\mathrm{BrO}$ columns show consistent results at this site. At ZPL, five of the six column $\mathrm{BrO}$ estimates show consistent correlation changes as a function of time lag except for OMI-RAQMS, which has the lowest correlation with $\mathrm{DC}-8 \mathrm{BrO}$ measurements (Fig. S1 in the Supplement). At Alert, the agreement among six tropospheric $\mathrm{BrO}$ columns is poor, due in part to a smaller number of ODEs (Fig. 1) and hence a lower (anti)correlation between ozone and column $\mathrm{BrO}$ and in part to the larger uncertainties in the tropospheric $\mathrm{BrO}$ column estimates at high latitude locations (Zeng et al., 2003; Choi et al., 2012).

At ZPL, the (anti)correlations are usually the largest in D0 or D-1, indicating a relatively strong influence of ozone loss in local and nearby regions. The results for Alert are ambiguous, although the general pattern of stronger D- 0 and D-1 (anti)correlations is consistent with the diurnal change of 10 th and 25 th percentile ozone discussed in the previous sec-
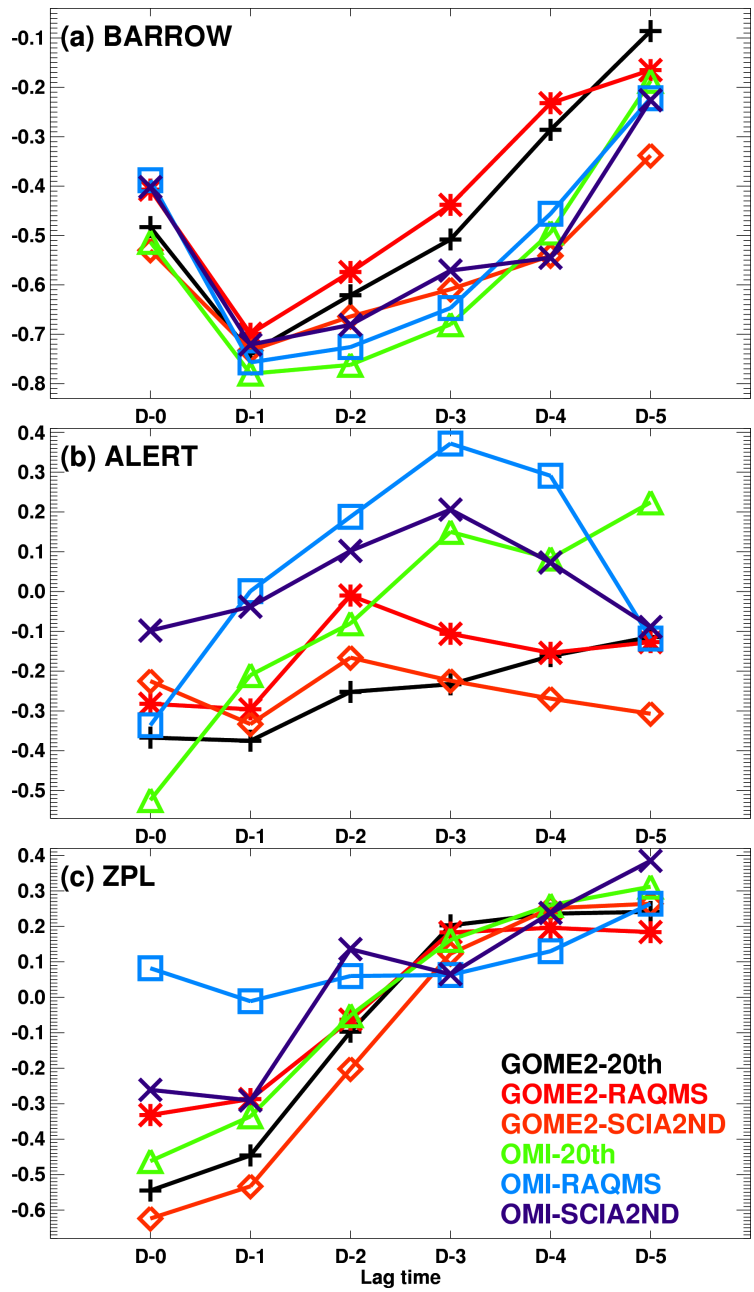

Fig. 3. Time-lagged daily mean correlation coefficients ( $R$ values) between surface ozone and tropospheric BrO VCD at (a) Barrow, (b) Alert, and (c) ZPL. D- $i$ denotes ozone correlation with BrO VCD taken along the back trajectories on the previous ith day (see text for details). We used six tropospheric BrO VCD estimates, GOME-2-20th (black), GOME-2-RAQMS (red), GOME-2SCIA2ND (orange), OMI-20th (green), OMI-RAQMS (blue), and OMI-SCIA2ND (violet).

tion. At Barrow, however, the (anti)correlations for D-1, D-2, and $\mathrm{D}-3$ are stronger than $\mathrm{D}-0$, suggesting a more significant transport effect than at the other two sites.

To demonstrate the change of transport patterns associated with ODEs, we show the patterns of two-day back trajectories for ODE (ozone mixing ratio $<20 \mathrm{ppbv}$ ) and non-ODE cases separately (Fig. 4). The largest transport difference is found at Barrow, suggesting a significant transport effect. During ODE periods, the air mass usually comes from the Chukchi Sea (the northwest of Barrow) where tropospheric BrO columns are high (Fig. 2). During non-ODE periods, however, air mass comes from the Beaufort Sea where we did not find the enhancement of tropospheric BrO. The patterns 

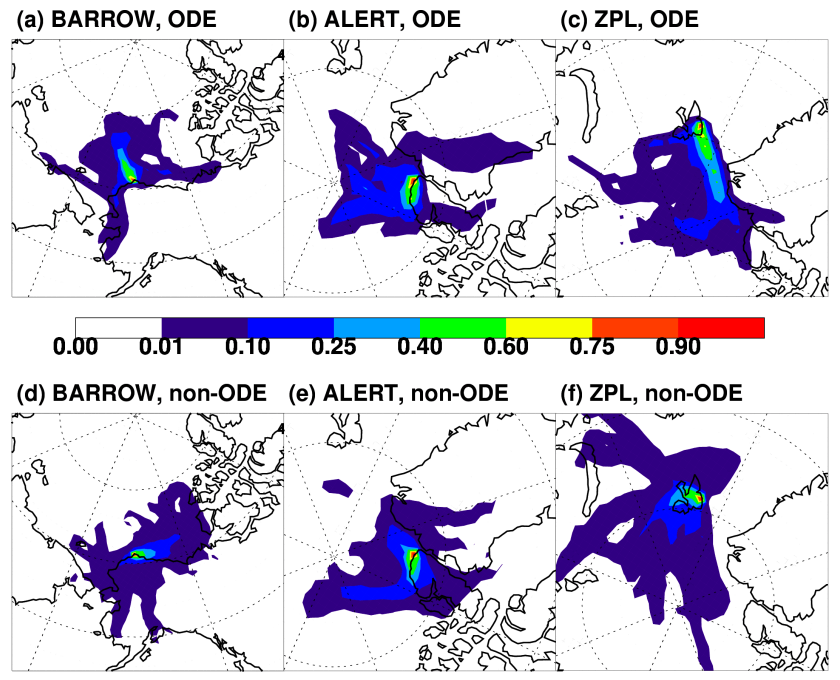

Fig. 4. Transport patterns using two-day back trajectories at (a) Barrow for ODEs, (b) Alert for ODEs, (c) ZPL for ODEs, (d) Barrow for non-ODEs, (e) Alert for non-ODEs, and (f) ZPL for non-ODEs. Color shows the probability of back trajectories passing through the grid box.

of back trajectories for ODEs and non-ODEs are similar at Alert, consistent with the potentially dominating effect of local chemistry (Figs. 1 and 3). At ZPL, the patterns of back trajectories for ODEs and non-ODEs are different but the difference is not as large as at Barrow. The ODE cases at this site are associated with transport from the northwest, but the non-ODE cases do not have a clear transport direction.

We obtained additional information by analyzing aircraft (NASA DC-8 and NOAA WP-3D) observations, which provide better regional coverage than surface sites. We found 34 ODE cases ( 9 from in situ measurements on DC-8, 12 cases from in situ measurements on WP-3D, and 13 cases from DC-8 UV-DIAL measurements), including 17 strong ODEs and 17 partial ODEs. Since the aircraft measurements cannot provide a time series of ozone at a given location, the correlation analysis of Fig. 3 cannot be performed with aircraft data. Instead, we calculated daily averaged $\mathrm{BrO}$ tropospheric columns along the two-day back trajectories (Fig. 5). Strong ODEs usually take place near the Chukchi Sea, a region with high tropospheric $\mathrm{BrO}$ columns. Note that the mean $\mathrm{BrO}$ column during the period of ARCTAS and ARCPAC experiments is shown in Fig. 5. However, partial ODEs are found over not only the Chukchi Sea, but also the Beaufort Sea. Partial ODEs over the Beaufort Sea are usually affected by transport from the Canadian Archipelago, another region of enhanced tropospheric $\mathrm{BrO}$ columns. On average, strong ODEs encountered higher tropospheric $\mathrm{BrO}$ columns than partial ODEs. The back trajectory results also show that the average BrO column encountered by ODEs and partial ODEs is highest at the day of measurement and decreases rapidly along the back trajectory in the previous 1-2 days,
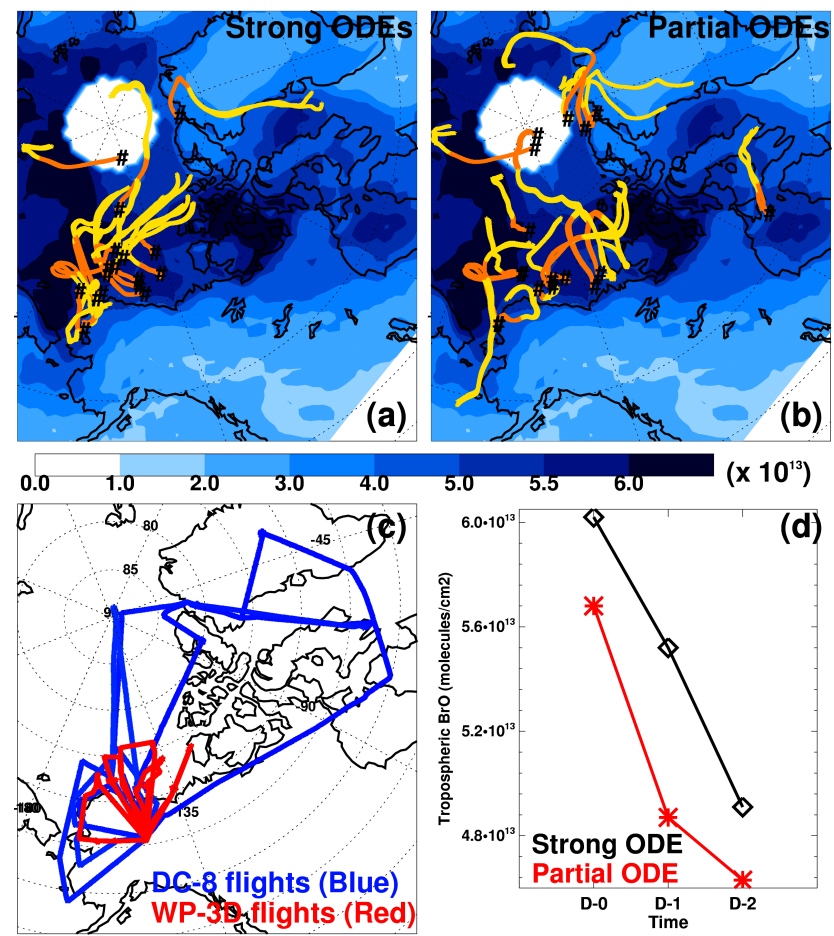

Fig. 5. Two-day back trajectories for (a) strong ODEs and (b) partial ODEs in aircraft measurements, (c) aircraft flight tracks, and (d) averaged tropospheric $\mathrm{BrO}$ columns along the back trajectories during strong and partial ODE periods. In panels (a) and (b), orange lines denote back trajectories up to 1 day, and yellow lines for 1-2 days prior to the time of ozone measurements. The average $\mathrm{BrO}$ columns during the period of aircraft measurements (from 1 to 21 April) are also shown in panels (a) and (b) with blue color shading. In panel (d), we averaged tropospheric BrO VCDs along the back trajectories with 0-, 1-, or 2-day time delays. The GOME-2-SCIA2ND BrO VCDs are used here. Results using OMI-SCIA2ND, GOME-2-20th, OMI-20th, GOME-2-RAQMS, and OMI-RAQMS BrO VCDs show similar patterns (Figs. S10, S11, S12, S13 and S14).

implying that transport is not as large a contributor as in situ chemical loss to the observed ODEs.

The northern region of Alaska appears to be affected mostly by ozone-poor air masses originating from the Chukchi Sea. Transport from the Canadian Archipelago that also had high BrO loading does not contribute to ODEs significantly in this region. Previously, Zhao et al. (2008) and Begoin et al. (2010) also showed that the Chukchi Sea is the dominant source of ozone-poor air mass with high tropospheric $\mathrm{BrO}$ and transport from this region may affect surface monitoring sites at northern high latitudes. In general, both aircraft and surface measurements (at Barrow) suggest that the duration of transport effects is within 2 days.

These findings do not rule out the existence of the large scale and long-range transport of ozone-poor air mass in the Arctic spring found by Bottenheim et al. (2009) and Jacobi et al. (2010). One possible explanation for the lack of 
evidence of long-range transport in this study is that we did not observe ODEs lasting as long as what was found in these two previous studies (Fig. 1). The large scale and long-range transport of low-ozone air mass would result in local ODEs lasting a few days. Since these two previous studies did not have a quantitative proxy for $\mathrm{BrO}$ concentrations, the method we developed in this study could be used to quantify the time lag between the occurrence and the time of observation of an ODE.

\subsubsection{The influence of temperature on ODEs}

There are indications that ozone depletion is stronger in cold conditions (e.g., Zeng et al., 2003; Pöhler et al., 2010; Nghiem et al., 2012). Recently, Seabrook et al. (2011) reported DIAL observations of ODEs at $60-700 \mathrm{~m}$ from 9 March to 2 April 2008 in the Amundsen Gulf $\left(71^{\circ}\right.$ N, 121$\left.124^{\circ} \mathrm{W}\right)$. They found a general correlation of ODEs with low temperature and that all ODEs occur below $-25^{\circ} \mathrm{C}$. For the purpose of comparison, we show in the supplement (Fig. S15) the relationship between ozone and temperature at Barrow which is located at the same latitude as the Amundsen Gulf. While most of the ODEs in February occurred at temperature lower than $-25^{\circ} \mathrm{C}$, a significant portion of ODEs in March occurred at temperature warmer than $-25^{\circ} \mathrm{C}$. ODEs in April and May are associated with even warmer temperatures $\left(<-8{ }^{\circ} \mathrm{C}\right.$ in April and $<-3{ }^{\circ} \mathrm{C}$ in May, not shown).

The warming trend in spring could potentially mask the relationship between ODE and temperature. In our investigation of this relationship, we first removed the linear trends in temperature and ozone, and then computed linear correlations between de-trended daily surface ozone and temperature at Barrow, Alert, and ZPL (Fig. 6). We also show the correlations between aircraft measured ozone and potential temperature $(0-1 \mathrm{~km})$. Potential temperature is used for aircraft measurements to account for temperature variations with altitude. Since the effect of temperature on ozone will likely take time to develop, we used daily average for the surface data and the average of each ODE encounter for aircraft data. Significant correlations $(R=0.63-0.80)$ are obtained for the three surface sites. Despite the large spatial coverage of aircraft data, where surface and transport conditions vary, a moderate correlation $(R=0.51)$ is still obtained between ozone and potential temperature.

Mechanisms responsible for the observed positive correlations between ozone and temperature have been proposed in the literature. The formation of a stable boundary layer could be a necessary condition to reduce the exchange of ozone-depleted air mass with ozone-rich air mass above the inversion layer (Tarasick and Bottenheim, 2002; Lehrer et al., 2004), and to enhance the efficiency of ozone depletion by bromine (Jacobi et al., 2010). Pöhler et al. (2010) proposed, on the other hand, that open ocean surface is warmer than the ambient atmosphere in the Arctic spring. When cold
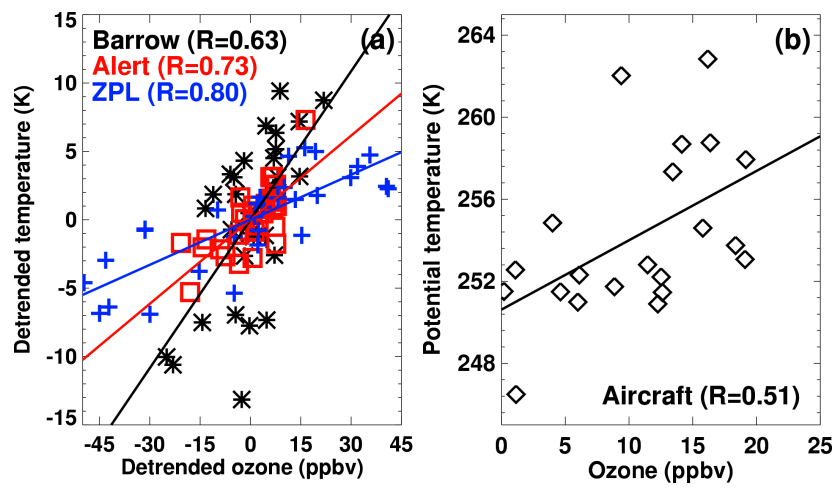

Fig. 6. (a) Correlations between the de-trended daily average ozone and temperature at Barrow (black), Alert (red), and ZPL (blue), and (b) correlations between average ozone and potential temperature for ODEs in aircraft measurements.

air mass moves over the open leads, the increased temperature gradient enhances the atmospheric exchange allowing a greater release of bromine from the ocean to the atmosphere, which leads to more frequent ODEs.

Another question yet to be answered is if there exists a threshold of temperature below which ODEs tend to occur. ODEs often occur at temperatures $<-20^{\circ} \mathrm{C}$ (Tarasick and Bottenheim, 2002). We discussed previously the more recent DIAL observations of a threshold temperature value of $-25^{\circ} \mathrm{C}$ by Seabrook et al. (2011). Examining surface and aircraft measurements in this analysis or the observations at Barrow since 1979, we did not find a clear threshold value of temperature for the occurrence of ODEs. This result is consistent with other recent studies (Bottenheim et al., 2009; Jacobi et al., 2010; Neuman et al., 2010). Our analysis indicates that a potentially important parameter is temperature variation, i.e., ODEs tend to occur during periods of decreasing temperature (Zeng et al., 2003). The temperature variation could be a reflection of the pressure change related to the change of synoptic conditions (Jacobi et al., 2010). However, the proposed mechanism of a large-scale pool of ozonepoor air mass coupled with a stable boundary layer and longrange transport does not seem to apply to the observations presented in this study because the durations of ODEs in this study are much shorter than those analyzed by Jacobi et al. (2010) and the ODEs are either in situ or enhanced by short-range (1-2 days) transport.

\subsection{Vertical structure of the ODEs}

Previous studies reported that Arctic ODEs could occur above the boundary layer (Tarasick and Bottenheim, 2002; Zeng et al., 2006) up to $1500 \mathrm{~m}$ (Strong et al., 2002). The large vertical extent of an ODE can be driven either by an equally deep $\mathrm{BrO}$ layer or by mixing with ozone-depleted air masses from the boundary layer. We make use of the extensive ozonesonde measurements at three sites, Barrow, 

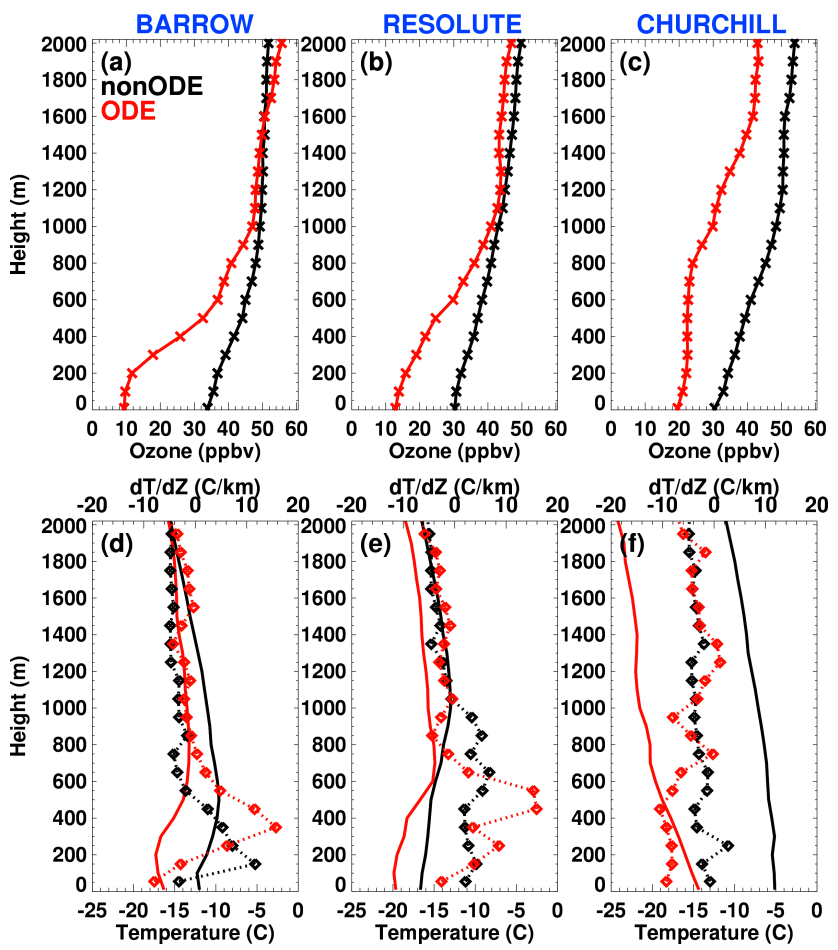

Fig. 7. Mean vertical profiles of ozone in the top row, and temperature (solid lines) and its lapse rate (dashed lines) in the bottom row for ODE (red) and non-ODE (black) periods in the ARCIONS campaign at Barrow, Resolute, and Churchill (Sect. 2.1.1). ODEs were observed for 6 days at Barrow and Resolute, and 2 days at Churchill.

Resolute, and Churchill during the ARCIONS campaign to examine the vertical structure of the ODEs.

We first compare the vertical profiles of the ozone and temperature for ODE and non-ODE cases (Fig. 7). The vertical extent of ODEs varied greatly by site. At Barrow, ozone increases rapidly above $200 \mathrm{~m}$. Similarly the average depth of ODEs at Resolute is about $300 \mathrm{~m}$, although the increase of ozone with altitude is not as drastic as in Barrow at $200 \mathrm{~m}$. In contrast, weak ODEs at Churchill extend almost uniformly to about $800 \mathrm{~m}$ similar to previous ODEs observed up to $2 \mathrm{~km}$ altitude in this region (Ridley et al., 2003). More striking is the difference of ozone profiles between ODE and non-ODE cases. At Churchill, the difference extends to $2 \mathrm{~km}$. At Resolute, large differences are seen up to $800 \mathrm{~m}$ and small difference also extended to $2 \mathrm{~km}$. Only at Barrow, the difference disappeared above $1 \mathrm{~km}$.

In contrast to the ozone profiles, ODE cases have lower temperature than non-ODE cases at all three sites up to $2 \mathrm{~km}$. The largest temperature difference is at Churchill. We also show the temperature lapse rate $(\mathrm{d} T / \mathrm{d} z)$ in Fig. 7 to examine the vertical stability of the boundary layer. At Barrow and Resolute, a clear temperature inversion (positive lapse rate) layer of $400 \mathrm{~m}$ forms not near the surface but above $200 \mathrm{~m}$ during ODEs. The temperature inversion layer at Resolute is 100-300 m higher than at Barrow, leading to a deeper ODE layer at the site than in Barrow. During non-ODE periods, the inversion is weaker at both sites. Analysis in the previous sections suggests the influence of transport of ozone-poor air mass to Barrow, and the strong inversion layer during ODEs is essential to suppress mixing from above and to maintain low ozone below the temperature inversion layer.

The latitude of Churchill $\left(58.7^{\circ} \mathrm{N}\right)$ is lower than the other surface and ozonesonde sites, and the regions sampled by aircraft. We find a very different vertical temperature structure at this site from Barrow and Resolute. The surface temperature gradient is about $-10 \mathrm{~K} \mathrm{~km}^{-1}$, implying strong vertical mixing. From surface to $2 \mathrm{~km}$, there is no temperature inversion layer during ODEs, although an isothermal layer existed at around $1.2 \mathrm{~km}$. In general, the thermal stability is weaker during ODE than non-ODE cases up to $700 \mathrm{~m}$, which is opposite to Barrow and Resolute. The effect of vertical mixing is reflected in the consistent ozone difference between ODE and non-ODE cases up to $2 \mathrm{~km}$.

We showed in Fig. 6 positive correlations between ozone and temperature during ODEs in surface and aircraft observations. Here we calculated the linear correlations between ozone and potential temperature from the ozonesonde measurements. Figure 8 shows the vertical profiles of linear correlations at Barrow, Resolute, and Churchill. At Barrow, below the thermal inversion layer, a large positive correlation is found $(R>0.6)$. Above the inversion layer, $R$ values decrease rapidly. At Resolute and Churchill, however, the positive correlation $(R>0.6)$ extends to $>2 \mathrm{~km}$ and $\sim 1.5 \mathrm{~km}$, respectively. It is interesting to note that at all three sites the correlation increases with altitude from the surface in the lower $300 \mathrm{~m}$, reflecting in part the increasing thermal stability away from the surface (Fig. 7).

Ozonesonde measurements provided additional information not available from surface and aircraft data. We investigate now if and how tropospheric $\mathrm{BrO}$ columns relate to the vertical structure of ODEs. Similar to the analysis in Sect. 3.1, the temporal correlations between time lagged (D-0 to D-5) BrO columns and ozonesonde measurements in the ARCIONS campaign were calculated at a given altitude from the surface to $2 \mathrm{~km}$. Figure 9 shows vertical profiles of correlation coefficients at Barrow, Resolute, and Churchill. At Barrow, a strong negative correlation near the surface is consistent with the analysis using surface ozone measurements (Fig. 3). The 1-day delayed $\mathrm{BrO}$ column has the largest negative correlation with ozone, implying the effect of short-range transport. The magnitude of negative $R$ values decreases rapidly above $400 \mathrm{~m}$, consistent with the ozone and thermal stability structure (Figs. 7 and 8), suggesting that $\mathrm{BrO}$ driven ozone loss is limited to the shallow boundary layer.

At Resolute and Churchill, the layer of significant negative correlation $(|r|>0.5)$ between ozone and $\mathrm{BrO}$ columns extends to $\sim 1 \mathrm{~km}$ and $2 \mathrm{~km}$ respectively. In the altitude range of ODEs (Fig. 7), the largest correlations are between concurrent ozone and $\mathrm{BrO}(\mathrm{D}-0)$ data, suggesting that transport 


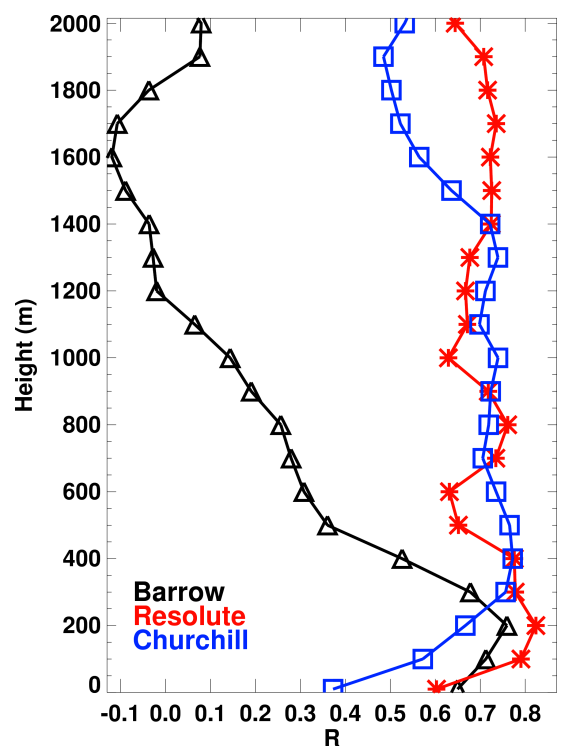

Fig. 8. Vertical profiles of linear correlation coefficients ( $R$ values) between potential temperatures and the ozone data measured by ozonesonde in the ARCIONS campaign at Barrow (black), Resolute (red), and Churchill (blue).

is not a significant factor for ODEs at Resolute. However, the correlation at Churchill is the largest with 1-day (D-1) or 2day (D-2) delayed $\mathrm{BrO}$ below $600 \mathrm{~m}$, indicating the effect of transport. Back trajectory analysis shows that the transport was from the Canadian Archipelago, a region with enhanced tropospheric $\mathrm{BrO}$ (Fig. 2), which is consistent with findings during the TOPSE experiment (Ridley et al., 2003; Zeng et al., 2003).

The correlation analysis of ozone with potential temperature (Fig. 8) and tropospheric $\mathrm{BrO}$ columns (Fig. 9) suggests that the vertical extent of BrO-driven ozone loss is larger than that of ODEs (Fig. 7). In particular, we find significant negative correlations between ozone and tropospheric $\mathrm{BrO}$ column in the free troposphere at Churchill. The strong negative correlation of ozone with current (D-0) or 1-day delayed (D-1) $\mathrm{BrO}$ extends from $600 \mathrm{~m}$ to $2 \mathrm{~km}$ altitude (Figs. 7 and 9). In contrast, the negative correlation between ozone and tropospheric $\mathrm{BrO}$ column is weaker near the surface and has a longer time delay (1-2 days) in the unstable boundary layer. Convective transport of boundary layer $\mathrm{BrO}$ into the free troposphere is possible at this site. McElroy et al. (1999) first reported the evidence of free-tropospheric $\mathrm{BrO}$ based on aircraft measurements, and hypothesized that the freetropospheric $\mathrm{BrO}$ is lofted from the surface by the strong convection. Begoin et al. (2010) showed strong upward lifting up to $3 \mathrm{~km}$ over the high-BrO region in the Arctic.
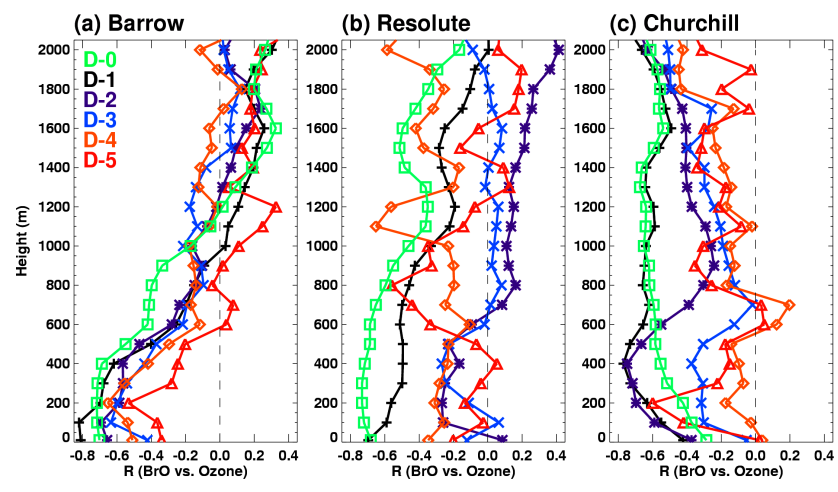

Fig. 9. Vertical profile of linear correlation coefficients (R values) between time-lagging tropospheric BrO VCDs (D-0, D-1, D-2, D-3, D-4, and D-5) and ozone data measured by ozonesonde at (a) Barrow, (b) Resolute, and (c) Churchill. The GOME-2-SCIA2ND BrO VCDs are used here. Results using OMI-SCIA2ND, GOME-2-20th, OMI-20th, GOME-2-RAQMS, and OMI-RAQMS BrO VCDs show similar patterns (Figs. S16, S17, S18, S19 and S20).

\section{Discussion of tropospheric column BrO retrieval validation}

Retrievals of tropospheric $\mathrm{BrO}$ columns from satellite observations have large uncertainties. In order to deal with these uncertainties, we used 3 different methods to estimate the stratospheric $\mathrm{BrO}$ columns (including stratospheric $\mathrm{BrO}$ observations from SCIAMACHY) with two satellite products (GOME-2 and OMI) to produce 6 estimates of tropospheric $\mathrm{BrO}$ columns. Despite the difference of correlations with in situ measurements of bromine compounds ( $\mathrm{BrO}, \mathrm{Br}_{2}+\mathrm{HOBr}$, and soluble bromide), the satellite products showed generally consistent correlation characteristics with ozone measurements, i.e., the correlation change (not necessarily the correlation values) with time or altitude is consistent. One exception is in the correlation analysis of Alert surface ozone, possibly indicating that applications of satellite column $\mathrm{BrO}$ to the high latitudes $\left(>80^{\circ} \mathrm{N}\right)$ require more careful scrutiny. The consistency in the diverse datasets of surface, ozonesonde, and aircraft ozone measurements implies that the estimated tropospheric $\mathrm{BrO}$ column can be effectively used to understand ODE characteristics in the Arctic spring.

An important question that we have not yet directly addressed is the feasibility of validating tropospheric column $\mathrm{BrO}$ estimates with in situ observations. We discuss here the constraints of in situ measurements on tropospheric column $\mathrm{BrO}$ estimates and the implications for validating satellite $\mathrm{BrO}$ measurements. First, we point out that the analysis approach we used in this study is somewhat different from the work by Choi et al. (2012), who carried out detailed case studies. While providing rich information on selected cases, the selection of cases is subjective and can inadvertently lead to qualitative arguments difficult to ascertain quantitatively 
with available measurements. The analysis approach in this study is based on the correlation statistics using all the measurement data. It does not provide the rich context of a case study, but it provides a more robust quantitative measure for data validation. We chose to use the method of linear regression, for example, between satellite column and in situ measurements of $\mathrm{BrO}$. One caveat in this type of data validation analysis is that there is only one degree of freedom left (a constant to adjust) when the correlation between the two datasets is good. In other words, it is usually not difficult to match the magnitudes of the two datasets when the correlation is good. When the correlation is not good, there is little reason to compare the magnitudes between the two datasets. The quality of correlation is therefore fundamentally more important for initial data validation than the magnitude comparison.

During the ARCTAS experiment, $\mathrm{BrO}$ measurements were available in only two flights on 16 and 17 April. Previous studies (Choi et al., 2012; Liao et al., 2012) showed good correlations between satellite retrieved $\mathrm{BrO}$ columns and in situ observations. Although we did not use the same satellite $\mathrm{BrO}$ product in this study, we found high correlations in several column BrO estimates (Fig. S1 in the Supplement). In contrast, neither Choi et al. (2012) (Table 4 of their paper) nor this study found significant correlation between satellite retrieved tropospheric column $\mathrm{BrO}$ and in situ $\mathrm{BrO}$ observations from 5 ARCPAC flights (12, 15, 18, 19, and 21 April). The reason is unclear. We note that there are 4 different estimates of stratospheric column $\mathrm{BrO}$ and two satellite total column measurements by combining Choi et al. (2012) with this study, which captures a reasonable range of variations for stratospheric column BrO estimates. The ARCTAS measurements were obtained further north, where there were a higher fraction of $\mathrm{BrO}$ measurements above the detection limit compared to the ARCPAC measurements. Without additional $\mathrm{BrO}$ measurements, a true validation study based on in situ $\mathrm{BrO}$ measurements is therefore infeasible.

One approach is to conduct correlation analysis between tropospheric $\mathrm{BrO}$ column and other related in situ observations. The measurements of $\mathrm{Br}_{2}+\mathrm{HOBr}$ were reported for 7 ARCTAS fights and 5 ARCPAC flights (Neuman et al., 2010; Liao et al., 2012) and soluble bromide measurements were also available in the ARCTAS flights (Liao et al., 2012). These measurements were more abundant and had more data points above the detection limits than $\mathrm{BrO}$ measurements. Figures S2-4 in the Supplement show that the products having higher correlations with ARCTAS $\mathrm{BrO}$ also tend to have higher correlations with $\mathrm{Br}_{2}+\mathrm{HOBr}$ and soluble bromide measurements from the ARCTAS and ARCPAC experiments since a large portion of correlations is driven by the absence and presence of bromine species along the flight tracks (not the absolute values of bromine species).

Comparison with the in situ bromine measurements showed that the six tropospheric $\mathrm{BrO}$ estimates are different. The reasons could be arising from the difference in the process to obtain the tropospheric $\mathrm{BrO}$ columns such as the retrieval algorithm and the estimates of the stratospheric $\mathrm{BrO}$ columns, and also from the difference of total $\mathrm{BrO}$ column between OMI and GOME-2 due to the instrument sensitivity and cloud interference. Currently there are no adequate measurements to resolve the quantitative contribution from these factors to the differences of all OMI and GOME-2 tropospheric BrO columns. In spite of the different correlations with in situ bromine measurements, the six tropospheric $\mathrm{BrO}$ estimates showed generally consistent correlation results with ozone, demonstrating a clear relationship between ozone and $\mathrm{BrO}$ when ODEs occurred.

Considering the observations available from the ARCTAS and ARCPAC experiments, the current quantitative constraints on the magnitudes of tropospheric (or stratospheric) $\mathrm{BrO}$ column are poor. However, judicious use of correlation analysis provides useful scientific insights into the processes of bromine-related ODEs as we have shown in this study. Our analysis results also help address two issues raised by previous studies (e.g., Choi et al., 2012 and references therein). The first is the concern that BrO-ozone anti-correlation will be suppressed during severe ODEs. This problem is partially dealt with in this study by analyzing time-lagged BrO-ozone correlations and we only find evidence of short-range transport of ODEs ( $<3$ days). The second issue is the potentially large contribution of stratospheric $\mathrm{BrO}$ column particularly over the Hudson Bay region, masking the tropospheric (low $\mathrm{BrO}$ ) signal. New observations that measure $\mathrm{BrO}$ through the entire tropospheric column are necessary to test this hypothesis. However, the correlation analysis of ozonesonde observations with satellite tropospheric $\mathrm{BrO}$ column at Churchill (Figs. 7, 8, and 9), an ozonesonde site near Hudson Bay, suggests an alternative hypothesis that the tropospheric $\mathrm{BrO}$ and ODE layers were much deeper (up to $2 \mathrm{~km}$ ) than at a site like Barrow (several hundred meters). In situ $\mathrm{BrO}$ and ozone observations might not measure drastic changes of ozone over such a region with enhanced tropospheric $\mathrm{BrO}$ column since the distribution of the $\mathrm{BrO}$ column enhancement into a deep layer reduced average $\mathrm{BrO}$ concentrations and ozone loss is also mitigated by the vertical mixing of a large volume of air due to an unstable boundary layer.

\section{Conclusions}

Based on surface, aircraft and ozonesonde measurements, satellite-derived tropospheric $\mathrm{BrO}$ vertical columns, and back trajectory calculations, we investigated characteristics of the Arctic ODEs in spring 2008. In situ observations from these experiments are inadequate to validate tropospheric $\mathrm{BrO}$ columns derived from satellite measurements (more detailes are discussed in the previous section). In view of this difficulty, we construct an ensemble of tropospheric column $\mathrm{BrO}$ estimates from two satellite measurements (OMI and GOME-2) and with three independent methods of calculating 
stratospheric $\mathrm{BrO}$ columns. Furthermore, we select analysis methods that do not depend on the absolute magnitude of column $\mathrm{BrO}$, such as time-lagged correlation analysis of $\mathrm{O}_{3}$ and tropospheric column $\mathrm{BrO}$, to understand characteristics of ODEs.

Time-lagged correlation analysis between ozone and tropospheric $\mathrm{BrO}$ columns allowed us to examine the relative importance of in situ ozone loss and transport. We did not find evidence for significant long-range ( $\geq 3$ days) transport. ODEs appeared to occur within 1-2 day transport from the $\mathrm{BrO}$ source regions. The effect of in situ ozone loss is also evident in the diurnal variation difference between low (10th and 25th percentiles) and higher percentiles of surface ozone concentrations at Alert, Canada. Analysis of tropospheric $\mathrm{BrO}$ columns along back trajectories of flight tracks showed low-ozone air mass transported from adjacent high-BrO regions.

There was a significant correlation between ozone and temperature in surface, ozonesonde, and aircraft data, but we did not find evidence for a threshold temperature value, which implies that the variation of temperature is a stronger factor than the value of temperature in ODE formation. During the ARCTAS and ARCPAC experiments, the BrO enhancement over the Chukchi Sea revealed by satellite measurements appears to be a major contributor to the ODEs observed by aircraft.

Both Barrow and Resolute are capped by an inversion layer at 400 and $600 \mathrm{~m}$ above the surface, respectively, below which ODEs occur at these sites. In contrast, the boundary layer at Churchill is unstable from the surface to $500 \mathrm{~m}$. At this site, we find a much deeper layer of ozone loss (up to $2 \mathrm{~km}$ ) than the other two sites. The depth of the ozone loss layer is corroborated in the correlation analysis of ozone with tropospheric BrO column and potential temperature. The unstable boundary layer during ODEs could potentially provide a source of free-tropospheric $\mathrm{BrO}$ through convective transport and explain the significant negative correlation between free-tropospheric ozone and tropospheric $\mathrm{BrO}$ column at this site. In situ observations of bromine species will be needed to confirm and understand the sources and recycling of $\mathrm{BrO}$ in the free troposphere.

\section{Supplementary material related to this article is available online at: http://www.atmos-chem-phys.net/12/ 9909/2012/acp-12-9909-2012-supplement.pdf.}

Acknowledgements. This work was supported by the NASA International Polar Year (IPY) Program. We thank Sungyeon Choi for processing the tropospheric column $\mathrm{BrO}$ estimates used in this study. The ozone data at Alert were supplied by Mike Shaw and Dave Ord from the Canadian Air and Precipitation Monitoring Network (CAPMoN) of Environment Canada. We thank Tao Zeng for the development of the back trajectory model.

Edited by: J. W. Bottenheim

\section{References}

Anlauf, K. G., Mickle, R. E., and Trivett, N. B. A.: Measurement of ozone during Polar Sunrise Experiment 1992, J. Geophys. Res., 99, 25345-25353, 1994.

Arimoto, R., Zeng, T., Davis, D., Wang, Y., Khaing, H., Nesbit, C., and Huey, G.: Concentrations and sources of aerosol ions and trace elements during ANTCI-2003, Atmos. Environ., 42, 28642876, 2008.

Barrie, L. A., Bottenheim, J. W., Schnell, R. C., Crutzen, P. J., and Rasmussen, R. A.: Ozone destruction and photochemical reactions at polar sunrise in the lower Arctic atmosphere, Nature, 334, 138-141, 1988.

Begoin, M., Richter, A., Weber, M., Kaleschke, L., Tian-Kunze, X., Stohl, A., Theys, N., and Burrows, J. P.: Satellite observations of long range transport of a large $\mathrm{BrO}$ plume in the Arctic, Atmos. Chem. Phys., 10, 6515-6526, doi:10.5194/acp-10-65152010, 2010.

Bottenheim, J. W. and Chan, E.: A trajectory study into the origin of spring time Arctic boundary layer ozone depletion, J. Geophys. Res., 111, D19301, doi:10.1029/2006JD007055, 2006.

Bottenheim, J. W., Fuentes, J. D., Tarasick, D. W., and Anlauf, K. G.: Ozone in the Arctic lower troposphere during winter and spring 2000 (ALERT2000), Atmos. Environ., 36, 2535-2544, 2002.

Bottenheim, J. W., Netcheva, S., Morin, S., and Nghiem, S. V.: Ozone in the boundary layer air over the Arctic Ocean: measurements during the TARA transpolar drift 2006-2008, Atmos. Chem. Phys., 9, 4545-4557, doi:10.5194/acp-9-4545-2009, 2009.

Brock, C. A., Cozic, J., Bahreini, R., Froyd, K. D., Middlebrook, A. M., McComiskey, A., Brioude, J., Cooper, O. R., Stohl, A., Aikin, K. C., de Gouw, J. A., Fahey, D. W., Ferrare, R. A., Gao, R.-S., Gore, W., Holloway, J. S., Hübler, G., Jefferson, A., Lack, D. A., Lance, S., Moore, R. H., Murphy, D. M., Nenes, A., Novelli, P. C., Nowak, J. B., Ogren, J. A., Peischl, J., Pierce, R. B., Pilewskie, P., Quinn, P. K., Ryerson, T. B., Schmidt, K. S., Schwarz, J. P., Sodemann, H., Spackman, J. R., Stark, H., Thomson, D. S., Thornberry, T., Veres, P., Watts, L. A., Warneke, C., and Wollny, A. G.: Characteristics, sources, and transport of aerosols measured in spring 2008 during the aerosol, radiation, and cloud processes affecting Arctic Climate (ARCPAC) Project, Atmos. Chem. Phys., 11, 2423-2453, doi:10.5194/acp-11-24232011, 2011.

Bromwich, D. H., Cassano, J. J., Klein, T., Heinemann, G., Jines, K. M., Steffen, K., and Box, J. E.: Mesoscale modeling of katabatic winds over Greenland with the polar MM5, Mon. Weather Rev., 129, 2290-2309, 2001.

Browell, E. V., Hair, J. W., Butler, C. F., Grant, W. B., DeYoung, R. J., Fenn, M. A., Brackett, V. G., Clayton, M. B., Brasseur, L. A., Harper, D. B., Ridley, B. A., Klonecki, A. A., Hess, P. G., Emmons, L. K., Tie, X., Atlas, E. L., Cantrell, C. A., Wimmers, A. J., Blake, D. R., Coffey, M. T., Hannigan, J. W., Dibb, J. E., Talbot, R. W., Flocke, F., Weinheimer, A. J., Fried, A., Wert, B., Snow, J. A., and Lefer, B. L.: Ozone, aerosol, potential vorticity, and trace gas trends observed at high latitudes over North America from February to May 2000, J. Geophys. Res., 108, 8369, doi:10.1029/2001JD001390, 2003.

Choi, S., Wang, Y., Salawitch, R. J., Canty, T., Joiner, J., Zeng, T., Kurosu, T. P., Chance, K., Richter, A., Huey, L. G., Liao, 
J., Neuman, J. A., Nowak, J. B., Dibb, J. E., Weinheimer, A. J., Diskin, G., Ryerson, T. B., da Silva, A., Curry, J., Kinnison, D., Tilmes, S., and Levelt, P. F.: Analysis of satellite-derived Arctic tropospheric $\mathrm{BrO}$ columns in conjunction with aircraft measurements during ARCTAS and ARCPAC, Atmos. Chem. Phys., 12, 1255-1285, doi:10.5194/acp-12-1255-2012, 2012.

Dibb, J. E., Ziemba, L. D., Luxford, J., and Beckman, P.: Bromide and other ions in the snow, firn air, and atmospheric boundary layer at Summit during GSHOX, Atmos. Chem. Phys., 10, 99319942, doi:10.5194/acp-10-9931-2010, 2010.

Fan, S.-M. and Jacob, D. J.: Surface ozone depletion in Arctic spring sustained by bromine reactions on aerosols, Nature, 359, 522-524, 1992.

Fenn, M. A., Browell, E. V., Butler, C. F., Grant, W. B., Kooi, S. A., Clayton, M. B., Gregory, G. L., Newell, R. E., Zhu, Y., Dibb, J. E., Fuelberg, H. E., Anderson, B. E., Bandy, A. R., Blake, D. R., Bradshaw, J. D., Heikes, B. G., Sachse, G. W., Sandholm, S. T., Singh, H. B., Talbot, R. W., and Thornton, D. C.: Ozone and aerosol distributions and air mass characteristics over the South Pacific during the burning season, J. Geophys. Res., 104, 1619716212, doi:10.1029/1999JD900065, 1999.

Foster, K. L., Plastridge, R. A., Bottenheim, J. W., Shepson, P. B., Finlayson-Pitts, B. J., and Spicer C. W.: The role of $\mathrm{Br} 2$ and $\mathrm{BrCl}$ in surface ozone destruction at polar sunrise, Science, 291, 471474, 2001

Gilman, J. B., Burkhart, J. F., Lerner, B. M., Williams, E. J., Kuster, W. C., Goldan, P. D., Murphy, P. C., Warneke, C., Fowler, C., Montzka, S. A., Miller, B. R., Miller, L., Oltmans, S. J., Ryerson, T. B., Cooper, O. R., Stohl, A., and de Gouw, J. A.: Ozone variability and halogen oxidation within the Arctic and sub-Arctic springtime boundary layer, Atmos. Chem. Phys., 10, 10223-10236, doi:10.5194/acp-10-10223-2010, 2010.

Hausmann, M. and Platt, U.: Spectroscopic measurement of bromine oxide and ozone in the high Arctic during Polar Sunrise Experiment 1992, J. Geophys. Res., 99, 25399-25413, 1994.

Helmig, D., Oltmans, S. J., Carlson, D., Lamarque, J.-F., Jones, A., Labuschagne, C., Anlauf, K., and Hayden, K.: A review of surface ozone in the polar regions, Atmos. Environ., 41, 5138-5161, 2007.

Hopper, J. F., Barrie, L. A., Silis, A., Hart, W., Gallant, A. J., and Dryfhout, H.: Ozone and meteorology during the 1994 Polar Sunrise Experiment, J. Geophys. Res., 103, 1481-1492, 1998.

Jacob, D. J., Crawford, J. H., Maring, H., Clarke, A. D., Dibb, J. E., Emmons, L. K., Ferrare, R. A., Hostetler, C. A., Russell, P. B., Singh, H. B., Thompson, A. M., Shaw, G. E., McCauley, E., Pederson, J. R., and Fisher, J. A.: The Arctic Research of the Composition of the Troposphere from Aircraft and Satellites (ARCTAS) mission: design, execution, and first results, Atmos. Chem. Phys., 10, 5191-5212, doi:10.5194/acp-10-5191-2010, 2010.

Jacobi, H.-W., Kaleschke, L., Richter, A., Rozanov, A., and Burrows, J. P.: Observation of a fast ozone loss in the marginal ice zone of the Arctic Ocean, J. Geophys. Res., 111, D15309, doi:10.1029/2005JD006715, 2006.

Jacobi, H.-W., Morin, S., and Bottenheim, J. W.: Observation of widespread depletion of ozone in the springtime boundary layer of he central Arctic linked to mesoscale synoptic conditions, J. Geophys. Res., 115, D17302, doi:10.1029/2010JD013940, 2010.

Jones, A. E., Anderson, P. S., Begoin, M., Brough, N., Hutterli, M. A., Marshall, G. J., Richter, A., Roscoe, H. K., and Wolff, E. W.:
$\mathrm{BrO}$, blizzards, and drivers of polar tropospheric ozone depletion events, Atmos. Chem. Phys., 9, 4639-4652, doi:10.5194/acp-94639-2009, 2009.

Jones, A. E., Anderson, P. S., Wolff, E. W., Roscoe, H. K., Marshall, G. J., Richter, A., Brough, N., and Colwell, S. R.: Vertical structure of Antarctic tropospheric ozone depletion events: characteristics and broader implications, Atmos. Chem. Phys., 10, 7775-7794, doi:10.5194/acp-10-7775-2010, 2010.

Kalnay. E., Kanamitsu, M., Kistler, R., Collins, W., Deaven, D., Gandin, L., Iredell, M., Saha, S., White, G., Woollen, J., Zhu, Y., Chelliah, M., Ebisuzaki, W., Higgins, W., Janowiak, J., Mo, K. C., Ropelewski, C., Wang, J., Leetmaa, A., Reynolds, R., Jenne, R., and Joseph, D.: The NCEP/NCAR 40-year reanalysis project, B. Am. Meteorol. Soc., 77, 437-471, 1996.

Kaleschke, L., Richter, A., Burrows, J., Afe, O., Heygster, G., Notholt, J., Rankin, A. M., Roscoe, H. K., Hollwedel, J., Wagner, T., and Jacobi, H.-W.: Frost flowers on sea ice as a source of sea salt and their influence on tropospheric halogen chemistry, Geophys. Res. Lett., 31, L16114, doi:10.1029/2004GL020655, 2004.

Kurosu, T. and Chance, K.: OMBRO Readme file, available at: www.cfa.harvard.edu/atmosphere/Instruments/OMI/ PGEReleases/READMEs/OMBRO_v300_README.pdf, 2011.

Lehrer, E., Hönninger, G., and Platt, U.: A one dimensional model study of the mechanism of halogen liberation and vertical transport in the polar troposphere, Atmos. Chem. Phys., 4, 2427 2440, doi:10.5194/acp-4-2427-2004, 2004.

Liao, J., Huey, L. G., Scheuer, E., Dibb, J. E., Stickel, R. E., Tanner, D. J., Neuman, J. A., Nowak, J. B., Choi, S., Wang, Y., Salawitch, R. J., Canty, T., Chance, K., Kurosu, T., Suleiman, R., Weinheimer, A. J., Shetter, R. E., Fried, A., Brune, W., Anderson, B., Zhang, X., Chen, G., Crawford, J., Hecobian, A., and Ingall, E. D.: Characterization of soluble bromide measurements and a case study of BrO observations during ARCTAS, Atmos. Chem. Phys., 12, 1327-1338, doi:10.5194/acp-12-1327-2012, 2012.

McElroy, C. T., McLinden, C. A., and McConnell, J. C.: Evidence for bromine monoxide in the free tropospheric during the Arctic polar sunrise, Nature, 397, 338-341, 1999.

Michalowski, B. A., Francisco, J. S., Li, S.-M., Barrie, L. A., Bottenheim, J. W., and Shepson, P. B.: A computer model study of multiphase chemistry in the Arctic boundary layer during polar sunrise, J. Geophys. Res., 105, 15131-15545, 2000.

Neuman, J. A., Nowak, J. B., Huey, L. G., Burkholder, J. B., Dibb, J. E., Holloway, J. S., Liao, J., Peischl, J., Roberts, J. M., Ryerson, T. B., Scheuer, E., Stark, H., Stickel, R. E., Tanner, D. J., and Weinheimer, A.: Bromine measurements in ozone depleted air over the Arctic Ocean, Atmos. Chem. Phys., 10, 6503-6514, doi:10.5194/acp-10-6503-2010, 2010.

Nghiem, S. V., Rigor, I. G., Richter, A., Burrows, J. P., Shepson, P. B., Bottenheim, J., Barber, D. G., Steffen, A., Latonas, J., Wang, F., Stern, G., Clemente-Colón, P., Martin, S., Hall, D. K., Kaleschke, L., Tackett, P., Neuman, G., and Asplin, M. G.: Field and satellite observations of the formation and distribution of Arctic atmospheric bromine above a rejuvenated sea ice cover, J. Geophys. Res., 117, D00S05, doi:10.1029/2011JD016268, 2012.

Oltmans, S. J.: Surface ozone measurements in clean air, J. Geophys. Res., 86, 1174-1180, 1981.

Oltmans, S. J. and Levy, I. H.: Surface ozone measurements from a global network, Atmos. Environ., 28, 9-24, 1994. 
Oltmans, S. J., Johnson, B. J., and Harris, J. M.: Springtime boundary layer ozone depletion at Barrow, Alaska: Meteorological influence, year to year variation, and long-term change, J. Geophys. Res., 117, D00R18, doi:10.1029/2011JD016889, 2012.

Parrish, D. D., Aikin, K. C., Oltmans, S. J., Johnson, B. J., Ives, M., and Sweeny, C.: Impact of transported background ozone inflow on summertime air quality in a California ozone exceedance area, Atmos. Chem. Phys., 10, 10093-10109, doi:10.5194/acp10-10093-2010, 2010

Piot, M. and von Glasow, R.: The potential importance of frost flowers, recycling on snow, and open leads for ozone depletion events, Atmos. Chem. Phys., 8, 2437-2467, doi:10.5194/acp-82437-2008, 2008.

Pöhler, D., Vogel, L., Frieß, U., and Platt, U: Observation of halogen species in the Amundsen Gulf, Arctic, by active long-path differential optical absorption spectroscopy, Proc. Natl. Acad. Sci., 107, 6582-6587, 2010.

Richter, A., Wittrock, F., Eisinger, M., and Burrows, J. P.: GOME observations of tropospheric $\mathrm{BrO}$ in northern hemispheric spring and summer 1997, Geophys. Res. Lett., 25, 2683-2686, 1998.

Ridley, B. A., Atlas, E. L., Montzka, D. D., Browell, E. V., Cantrell, C. A., Blake, D. R., Blake, N. J., Cinquini, L., Coffey, M. T., Emmons, L. K., Cohen, R. C., DeYoung, R. J., Dibb, J. E., Eisele, F. L., Flocke, F. M., Fried, A., Grahek, F. E., Grant, W. B., Hair, J. W., Hannigan, J. W., Heikes, B. J., Lefer, B. L., Mauldin, R. L., Moody, J. L., Shetter, R. E., Snow, J. A., Talbot, R. W., Thornton, R. W., Walega, J. G., Weinheimer, A. J., Wert, B. P., and Wimmers, A. J.: Ozone depletion events observed in the high latitude surface layer during the TOPSE aircraft program, J. Geophys. Res., 108, 8356, doi:10.1029/2001JD001507, 2003.

Rozanov, A., Kühl, S., Doicu, A., McLinden, C., Pukite, J., Bovensmann, H., Burrows, J. P., Deutschmann, T., Dorf, M., Goutail, F., Grunow, K., Hendrick, F., von Hobe, M., Hrechanyy, S., Lichtenberg, G., Pfeilsticker, K., Pommereau, J. P., Van Roozendael, M., Stroh, F., and Wagner, T.: BrO vertical distributions from SCIAMACHY limb measurements: comparison of algorithms and retrieval results, Atmos. Meas. Tech., 4, 1319-1359, doi:10.5194/amt-4-1319-2011, 2011.

Sander, R. and Crutzen, P. J.: Model study indicating halogen activation and ozone destruction in polluted air masses transported to the sea, J. Geophys. Res., 101, 9121-9138, 1996.

Sander, R., Rudich, Y., von Glasow, R., and Crutzen, P. J.: The role of $\mathrm{BrNO}_{3}$ in marine tropospheric chemistry: A model study, Geophys. Res. Lett., 26, 2857-2860, 1999.

Seabrook, J. A., Whiteway, J., Staebler, R. M., Bottenheim, J. W., Komguem, L., Gray, L. H., Barber, D., and Asplin, M.: LIDAR measurements of Arctic boundary layer ozone depletion events over the frozen Arctic Ocean, J. Geophys. Res., 116, D00S02, doi:10.1029/2011JD016335, 2011.

Simpson, W. R., Carlson, D., Hönninger, G., Douglas, T. A., Sturm, M., Perovich, D., and Platt, U.: First-year sea-ice contact predicts bromine monoxide $(\mathrm{BrO})$ levels at Barrow, Alaska better than potential frost flower contact, Atmos. Chem. Phys., 7, 621-627, doi:10.5194/acp-7-621-2007, 2007.
Sinnhuber, B.-M., Rozanov, A., Sheode, N., Afe, O. T., Richter, A., Sinnhuber, M., Wittrock, F., and Burrows, J. P.: Global observations of stratospheric bromine monoxide from SCIAMACHY, Geophys. Res. Lett., 32, L20810, doi:10.1029/2005GL023839, 2005.

Solberg, S., Schmidbauer, N., Semb, A., and Stordal, F.,: Boundary layer ozone depletion as seen in the Norwegian Arctic in spring, J. Atmos. Chem., 23, 301-332, 1996.

Strong, C., Fuentes, J. D., Davis, R. E., and Bottenheim, J. W.: Thermodynamic attributes of Arctic boundary layer ozone depletion, Atmos. Environ., 36, 2641-2652, 2002.

Tang, T. and McConnell, J. C.: Autocatalytic release of bromine from Arctic snow pack during polar sunrise, Geophys. Res. Lett., 23, 2633-2636, 1996.

Tarasick, D. W. and Bottenheim, J. W.: Surface ozone depletion episodes in the Arctic and Antarctic from historical ozonesonde records, Atmos. Chem. Phys., 2, 197-205, doi:10.5194/acp-2197-2002, 2002.

Theys, N., Van Roozendael, M., Hendrick, F., Yang, X., De Smedt, I., Richter, A., Begoin, M., Errera, Q., Johnston, P. V., Kreher, K., and De Mazière, M.: Global observations of tropospheric BrO columns using GOME-2 satellite data, Atmos. Chem. Phys., 11, 1791-1811, doi:10.5194/acp-11-1791-2011, 2011.

Thompson, A. M., Oltmans, S. J., Tarasick, D. W., Von der Gathen, P., Smit, H. G. J., and Witte, J. C.: Strategic ozone sounding networks: Review of design and accomplishments, Atmos. Environ., 45, 2145-2163, doi:10.1016/j.atmosenv.2010.05.002, 2011.

Toyota, K., McConnell, J. C., Lupu, A., Neary, L., McLinden, C. A., Richter, A., Kwok, R., Semeniuk, K., Kaminski, J. W., Gong, S.-L., Jarosz, J., Chipperfield, M. P., and Sioris, C. E.: Analysis of reactive bromine production and ozone depletion in the Arctic boundary layer using 3-D simulations with GEM-AQ: inference from synoptic-scale patterns, Atmos. Chem. Phys., 11, 3949-3979, doi:10.5194/acp-11-3949-2011, 2011.

Vogt, R., Crutzen, P. J., and Sander, R.: A mechanism for halogen release from sea-salt aerosol in the remote marine boundary layer, Nature, 383, 327-330, 1996.

Yang, X., Pyle, J. A., Cox, R. A., Theys, N., and Van Roozendael, M.: Snow-sourced bromine and its implications for polar tropospheric ozone, Atmos. Chem. Phys., 10, 7763-7773, doi:10.5194/acp-10-7763-2010, 2010.

Zeng, T., Wang, Y., Chance, K., Browell, E. V., Ridley, B. A., and Atlas, E. L.: Widespread persistent near-surface ozone depletion at northern high latitudes in spring, Geophys. Res. Lett., 30, 2298, doi:10.1029/2003GL018587, 2003.

Zeng, T., Wang, Y., Chance, K., Blake, N., Blake, D., and Ridley, B.: Halogen-driven low-altitude $\mathrm{O}_{3}$ and hydrocarbon losses in spring at northern high latitudes, J. Geophys., Res., 111, D17313, doi:10.1029/2005JD006706, 2006.

Zhao, T. L., Gong, S. L., Bottenheim, J. W., McConnell, J. C., Sander, R., Kaleschke, L., Richter, A., Kergweg, A., Toyota, K., and Barrie, L. A.: A three-dimensional model study on the production of $\mathrm{BrO}$ and Arctic boundary layer ozone depletion, J. Geophys. Res., 113, D24304, doi:10.1029/2008JD010631, 2008. 